\title{
Innovative Method of Teaching English Language in Primary Schools Using Adaptive Interactive Animated Cartoons
}

\author{
Sofowora Olaniyi Alaba (PhD) \\ Ohafemi Awolowo University, lle-ife, Faculty of Education, Department of Educational Technology \\ oasofowora@oyahoo.com \& oasofowora@oauife.edu.ng
}

\section{Doi:10.5901/jesr.2014.v4n6p75}

\section{Abstract}

\begin{abstract}
This paper investigated the effectiveness of adaptive interactive cartoon animated package in teaching and learning English language in selected primary schools in Ife East Local Government Area of Osun State. This is with a view to improving the primary school pupils' pronunciation, reading and comprehension sub- skills in English Language. The study employed pretestposttest control group design by Campbell and Stanley (1992). The population for the study is made of all pupils in primary schools in Ife East Local Government Area of the State. Two schools were purposively selected based on availability of electricity and learning resource facilities. Two hundred primary school pupils were randomly selected from the 2 schools (1 public and 1 private primary school). Two research instruments namely; (i) Pupils attitude toward the Cartoon Animation and; (ii) Achievement questionnaire on reading spelling and pronunciation formed the materials used to collect data for this study. Precisely, the 200sample was selected from the primary six classes. The control group was taught using the didactic method while the experimental group was exposed to the package. After the treatment, a post- test was administered on the two groups. Results collected were analyzed using t-test . The results showed that pupils that were exposed to Adaptive Interactive Cartoon Animation performed significantly better than those taught English Language using the traditional method ( $t=14.67$, $d f=198, p<0.05)$. In addition, the use of Adaptive Interactive Cartoon Animation significantly enhanced pupils attitudes towards English Language ( $t=8.47, d f=198 P<0.05)$. It was concluded that Adaptive Interactive Cartoon Animation was an effective, creative and motivating method for teaching English Language in Nigerian primary schools.
\end{abstract}

Keywords: Adaptive, Animated cartoons, learning package, interaction, motivation and creativity

\section{Background}

It is evident that there are problems and challenges facing the teaching and learning of English language in our schools. This is revealed in the persistent high failure rates in the Junior and Secondary School Examinations. This decline in standard and poor performance of students in the secondary schools and even at the tertiary institutions could be traced to the foundation level which is the primary schools. As a result of the importance of English as one of the core /compulsory courses that students must pass at credit level. Many students have developed phobia for the subject thinking that it is one of the most difficult subjects. Also from the researcher's observation, as a member of the monitoring team during WAEC and NECO Examinations, securities are normally beefed up during English Language and Mathematics examinations. These subjects normally witness high rate of students who wanted to cheat in-order to pass. Many students every year consider English Language Examination as a do or die affair, this is because of the phobia developed as a result of persistent high failure rates every year round. The reasons for the students resulting to examination malpractice is because English Language is an important pre-requisite that every student must sit for and pass at credit level before gaining entry into any higher institution in Nigeria. The poor performances of students in this subject over the years have become a subject matter of public debate and news paper head lines. Prominent researchers that have studied the problems of teaching English Language are Egbowon (1986), Okobi (1992),Faniran (1994), 'Ayodele (2001), Egbowon (2005), Ajibade (2007) and Adokpaye (2008). Ayodele (2001) is of the view that the consistent mass failures of students in English Language have defiled right solution.

\section{Literature Review}

Egbonwon (2005) quoting Obemeata (1984) states that

Every year, for the past few years, the performance has tended to be worse than the previous years; however this year, 
there has been a noticeable decline in general and there is certainly grave concern about the standard of English Language teaching in our country (p.3.).

Egbowon (2005) also commenting on the above report observes that:

The standard of English Language papers compare favorably with those of previous years. The essay topics are well within the experience of average students in the final year examination... In spite of these advantages, candidates performance was still extremely disappointing. The main course of this poor performance is poor and insufficient preparation (p. 3).

Several factors have been attributed as the cause of poor performance of students in the subject. Ajibade (2007) attributed some, to lack of qualified teachers, heavy workload on the few available English Language teachers, dearth of relevant English textbook and attitude of students of English Language. Adopakye (2001) citing the West African Examination Council Chief Examiners Report of 2000 says that:

Candidate performance was inexplicably disappointing. The cause was due to students' inability to read and invite simple structural English (p. 3).

On the other hand, Ajibade (2007) states that:

most students perform badly because of their inability to express themselves correctly in simple English. They were ignorant of the approved orthography. Student's answers in English Language were marred by faulty grammar and structural English. It is disappointing that after six years of secondary school education, students demonstrated an ignorance of the fundamentals of English Language (p. 14).

Sofowora (2011) also identifies other problems like: overcrowded classrooms, stereotype method of teaching, poor facilities/infrastructure and lack of relevant instructional materials. The poor performance being recorded at the secondary school level could be traced back to the primary schools. There are many problems associated with primary education in the country.

\subsection{Challenges with Primary Education}

Primary education refers to the education given to children between 5 and 11 years. According to the National Policy on Education (2008, Revised Edition), the general objectives of primary education include:

- inculcation of permanent literacy and innumeracy and the ability to communicate effectively;

- laying a sound foundation for scientific and effective thinking participation and contribution to the society;

- giving the child opportunities to develop manipulative skills that will enable them to function effectively in the society within the limit of their capacity:

- provide basic, tools for further educational advancement, including preparation for trades and crafts of the locality (NPE p. 16).

To achieve the above educational goals, the Federal Government according to the National Policy on Education recommended a teacher -pupil ratio of 1 to 20 for pre-primary and 1:30 for primary schools. It was also clearly stated that provision will be made for Junior Library in all primary schools. The National Policy also make provision for the utilization of relevant instructional materials and modern technologies in the teaching of Integrated Science, Computer and Language Arts. They are also to establish Audio-Visual Aid Development Centre. Good as this white paper on primary education is, there are problems militating against its successful implementation. Most of the primary schools are in deplorable condition, the teacher-pupil ratio of 1 to 30 is yet to be achieved. Most of the schools lack library facilities and relevant instructional materials. There is high incidence of truancy/drop-out rates. According to Egwu (2009) while speaking on access and equality observes that wide disparity exists between the expected and the actual enrolments. According to him, the expected enrolment in primary schools is 34.92 million but the actual is 24.42 million leaving a shortfall of 10.50million. For Early Childhood Care Development and Education (ECCDE) the expected is 22 million while the actual is 2.02 million leaving 19.08 million out of school. Other problems according to Egwu $(2009$, p. 25) are:

- continuous production of half baked products who are not resourceful and globally competitive,

- low learning outcomes in literacy, innumeracy and life skills. In order to address these problems facing education at this level, certain quality control measures were put in place. They are ensuring that all the 
schools are staffed with qualified and competent teachers. According to the National Policy on Education and the Universal Basic Education (UBE Act), the minimum standard for teachers to teach in the primary schools in Nigeria is National Certificate in Education (See Table 1).

Table 1: Primary School teachers by TRCN zones and states nationwide (2007-2012)

\begin{tabular}{|c|c|c|c|c|c|c|}
\hline$S / N$ & Zones & $\begin{array}{c}\text { No of Public } \\
\text { primary school }\end{array}$ & $\begin{array}{c}\text { Number of } \\
\text { Teachers }\end{array}$ & No of qualified & $\begin{array}{c}\text { No unqualified } \\
\text { teaches }\end{array}$ & $\begin{array}{c}\% \text { of } \\
\text { Qualified }\end{array}$ \\
\hline \multicolumn{6}{|c|}{ North Central } & \\
\hline 1. & \begin{tabular}{|l} 
MINA ZONE \\
FCT \\
KOGI \\
KWARA \\
NIGER
\end{tabular} & $\begin{array}{c}457 \\
1207 \\
1433 \\
2628\end{array}$ & $\begin{array}{l}5529 \\
12353 \\
19094\end{array}$ & $\begin{array}{r}4779 \\
11045 \\
12638\end{array}$ & $\begin{array}{c}750 \\
1348 \\
3839\end{array}$ & $\begin{array}{c}86.40 \% \\
8910 \% \\
77 \% \\
74.10 \%\end{array}$ \\
\hline \multicolumn{2}{|r|}{ Total } & 5725 & 53490 & 42608 & 10882 & $79.70 \%$ \\
\hline 2 & $\begin{array}{l}\text { JOS ZONE IBENUE } \\
\text { NASARAA } \\
\text { PLATEAU }\end{array}$ & $\begin{array}{l}2435 \\
1161 \\
1951\end{array}$ & $\begin{array}{l}21336 \\
11392 \\
13466\end{array}$ & $\begin{array}{l}15955 \\
9652 \\
1339\end{array}$ & $\begin{array}{c}1377 \\
1730 \\
147\end{array}$ & $\begin{array}{l}93.60 \% \\
84.80 \% \\
98.90 \%\end{array}$ \\
\hline & Total & & 46194 & & 3254 & \\
\hline \multicolumn{7}{|c|}{ North East } \\
\hline \multirow[t]{2}{*}{3} & $\begin{array}{l}\text { YOLA ZONE } \\
\text { ADAMWA } \\
\text { GOMBE } \\
\text { TARABA }\end{array}$ & $\begin{array}{l}1620 \\
1034 \\
1495\end{array}$ & $\begin{array}{l}18008 \\
12184 \\
17300\end{array}$ & $\begin{array}{c}13825 \\
7216 \\
11947\end{array}$ & $\begin{array}{l}4183 \\
4968 \\
5353\end{array}$ & $\begin{array}{l}76.80 \% \\
59.20 \% \\
69.10 \%\end{array}$ \\
\hline & Total & 1620 & 47492 & 32988 & 14504 & $69.50 \%$ \\
\hline \multirow[t]{3}{*}{4} & \begin{tabular}{|l|} 
MAIDUGURI ZONE \\
BAUCH \\
BORNO \\
YOBE \\
\end{tabular} & $\begin{array}{l}1620 \\
1034 \\
1495\end{array}$ & $\begin{array}{l}18008 \\
12184 \\
17300\end{array}$ & $\begin{array}{l}13825 \\
7216 \\
11947\end{array}$ & $\begin{array}{l}4183 \\
4968 \\
5353\end{array}$ & $\begin{array}{l}76.80 \% \\
59.20 \% \\
69.10 \%\end{array}$ \\
\hline & Total & 4238 & 37640 & 28357 & 9283 & $75.30 \%$ \\
\hline & \multicolumn{6}{|c|}{ North West } \\
\hline 5 & \begin{tabular}{|l|} 
KADUNA ZONE \\
JIGAWA \\
KADUNA \\
KANO \\
KATSINA
\end{tabular} & $\begin{array}{l}1689 \\
2723 \\
3727 \\
2158\end{array}$ & $\begin{array}{l}1665 \\
26467 \\
15449 \\
19363\end{array}$ & $\begin{array}{c}1370 \\
20602 \\
10783 \\
12636\end{array}$ & $\begin{array}{c}295 \\
5865 \\
4666 \\
6727\end{array}$ & $\begin{array}{l}82.30 \% \\
77,80 \% \\
69.80 \% \\
65.30 \%\end{array}$ \\
\hline & TOTAL & 10297 & 62944 & 45391 & 17553 & $72.10 \%$ \\
\hline \multirow[t]{3}{*}{6} & $\begin{array}{l}\text { SOKOTO ZONE } \\
\text { KEBBI } \\
\text { SOKOTO } \\
\text { ZMFARA }\end{array}$ & $\begin{array}{l}1404 \\
1608 \\
1151\end{array}$ & $\begin{array}{c}2661 \\
11648 \\
9424\end{array}$ & $\begin{array}{l}2311 \\
4605 \\
6066\end{array}$ & $\begin{array}{c}350 \\
7043 \\
3356\end{array}$ & $\begin{array}{l}96.90 \% \\
39.50 \% \\
64,40 \%\end{array}$ \\
\hline & TOTAL & 4163 & 23733 & 12984 & 10749 & $54.70 \%$ \\
\hline & \multicolumn{6}{|c|}{ South East } \\
\hline \multirow[t]{2}{*}{7} & $\begin{array}{l}\text { OWERRI ZONE } \\
\text { ABIA } \\
\text { IMO } \\
\end{array}$ & $\begin{array}{r}793 \\
1263 \\
\end{array}$ & $\begin{array}{l}12160 \\
14914 \\
\end{array}$ & $\begin{array}{l}10112 \\
14029 \\
\end{array}$ & $\begin{array}{c}2048 \\
885 \\
\end{array}$ & $\begin{array}{l}83.20 \% \\
94.10 \%\end{array}$ \\
\hline & TOTAL & 2056 & 27074 I & 24141 & 2933 & $89.20 \%$ \\
\hline \multirow[t]{2}{*}{8} & \begin{tabular}{|l|} 
ENUGUN ZONE \\
ANAMBRA \\
EBONYI \\
ENUGU
\end{tabular} & $\begin{array}{l}1030 \\
1005 \\
1165\end{array}$ & $\begin{array}{l}14081 \\
10236 \\
15881\end{array}$ & $\begin{array}{c}12900 \\
4700 \\
15213\end{array}$ & $\begin{array}{c}1161 \\
5536 \\
668\end{array}$ & $\begin{array}{l}91.60 \% \\
45.90 \% \\
95.80 \%\end{array}$ \\
\hline & & 3200 & 40198 & 32813 & 7385 & $81.60 \%$ \\
\hline \multirow[t]{2}{*}{9} & \begin{tabular}{|l} 
UYO ZONE \\
AKWA-IBOM \\
CROSS RIVER \\
RIVERS
\end{tabular} & $\begin{array}{l}1130 \\
1019 \\
1046\end{array}$ & $\begin{array}{c}16651 \\
14080 \\
9129\end{array}$ & $\begin{array}{c}16288 \\
11169 \\
9129\end{array}$ & $\begin{array}{c}363 \\
2911 \\
-\end{array}$ & $\begin{array}{c}97.80 \% \\
79.30 \% \\
100.00 \%\end{array}$ \\
\hline & TOTAL & 3195 & 39860 & 36586 & 3274 & $91.60 \%$ \\
\hline
\end{tabular}




\begin{tabular}{|c|c|c|c|c|c|c|}
\hline 10 & $\begin{array}{l}\text { BENIN ZONE } \\
\text { BAYELSA } \\
\text { DELTA } \\
\text { EDO }\end{array}$ & $\begin{array}{c}546 \\
1436 \\
1113\end{array}$ & $\begin{array}{c}5746 \\
12157 \\
11451\end{array}$ & $\begin{array}{c}5035 \\
10952 \\
10769\end{array}$ & $\begin{array}{c}705 \\
1205 \\
682\end{array}$ & $\begin{array}{c}87.70 \% \\
90.10 \% \\
94.00\end{array}$ \\
\hline & Total & 3095 & 29354 & 26756 & 2592 & $91.20 \%$ \\
\hline & & & South West & & & \\
\hline \multirow[t]{2}{*}{11} & \begin{tabular}{|l} 
AKURE ZONE \\
EKITI \\
ONDO \\
OSUN
\end{tabular} & $\begin{array}{c}740 \\
1164 \\
1381 \\
\end{array}$ & $\begin{array}{c}8769 \\
13812 \\
13438 \\
\end{array}$ & $\begin{array}{c}8769 \\
12994 \\
13438 \\
\end{array}$ & $\begin{array}{c}- \\
818 \\
- \\
818\end{array}$ & $\begin{array}{c}100.00 \% \\
94.10 \% \\
100.00 \%\end{array}$ \\
\hline & Total & 3285 & 36019 & 35201 & & $97.70 \%$ \\
\hline \multirow[t]{3}{*}{12} & $\begin{array}{l}\text { LAGOS ZONE } \\
\text { LAGOS } \\
\text { OGUN } \\
\text { OYO }\end{array}$ & $\begin{array}{c}940 \\
1368 \\
1940\end{array}$ & $\begin{array}{l}43283 \\
16915 \\
33892 \\
\end{array}$ & $\begin{array}{l}26186 \\
16735 \\
29758 \\
\end{array}$ & $\begin{array}{c}17097 \\
180 \\
4134 \\
\end{array}$ & $\begin{array}{l}60.50 \% \\
98.90 \% \\
87.80 \%\end{array}$ \\
\hline & Total & 53212 & 94090 & 72679 & 104638 & $77.20 \%$ \\
\hline & Grand total & 53212 & 538088 & 433444 & 104638 & $82.00 \%$ \\
\hline
\end{tabular}

Source: Statistic Digest teachers Registration Council of Nigeria

The table shows the record of qualified and nonqualified teachers' nation wide. The official statistics revealed that Sokoto State has only $39 \%$ who were qualified, Ebonyi State has only $45.9 \%$, Borno has $59.20 \%$ qualified teachers. Osun State however as at 2011/2012 Session had 100\% of its teachers qualified. Other challenges include restructuring teaching and learning environment to be ICT-Driven, procurement of modern and relevant instructional materials. The ultimate aim of the above is to use modern technology to re-conceptualize the curriculum. This attempt was similar to the findings and research effort of Barnet and Milton (1995). According to Barnet and Milton (1995) on the need to increase classroom efficiency:

Two third of those who says they found school completely dull and uninteresting describe walking with ICT interesting. Half of those who claim they always behave badly at school get so much interested working with computer, which they don't want to stop (p142).

The implication of the above is that if relevant educational media are used in the teaching English Language at the basic level, it can encourage active learning, enhance creativity, and improve pupil's attitude and confidence in the subject. This is why Ayodele (1994) opines that relevant instructional materials can be used to solve the problems of poor performance of students in English Language. This assertion may be true, since literatures revealed that the predominant method of teaching is the didactic method, non usage of technically good and relevant instructional materials. Based on the above, the main thrust of this study is to investigate the extent to which Adaptive Interactive Cartoon Animation can be used to teach spelling, reading pronunciation and comprehension in English Language at the primary school level in Osun State in Nigeria.The poor performance of students in English Language in all examinations demands intervention. It was observed that the cause could be traced to the poor foundation in spelling, reading and phonological processing sub skills in the primary schools. The absence of these skills in English Language may have an untold effect on performance of students. It is against this background that this study was designed. This study was therefore designed to investigate if Adaptive Interactive Cartoon Animation can effectively improve the teaching and learning of English Language at the primary school level. This is with the ultimate aim of improving the performance of pupils in the subject.

\section{Research Objectives}

The objectives of this study are to:

(a) determine the effectiveness of Adaptive Interactive Cartoon Animation in enhancing the performance of pupils in English Language at primary schools in Nigeria; and

(b) investigate pupils' attitude towards Adaptive Interactive Cartoon Animation in the teaching/learning of English Language. 


\subsection{Research Hypotheses}

The study intends to provide empirical answer to the following research questions.

(i) There is no significant difference in the performance in the performance of pupils exposed to interactive cartoon animation and those taught using the traditional method.

(ii) There is no significant difference in the attitude of the pupils exposed to the interactive cartoon animation and those not exposed to it.

\subsection{Theoretical Framework}

This study is guided by the theory of Multi-media learning of Mayer (1997) and meaningful learning by Smith and Regan (1999). The multi-media Learning theory describes how learner builds mental representation of multi-media materials. It involves the integration of visual and verbal information. The integration process is what Mayer termed cognitive loading process. This school of thought also believes that there are extraneous load of instruction that must be kept as low as possible to allow learner use his/her mental resource for the actual learning process. Moren and Mayer (2000) call .this meaningful learning. According and Smith and Regan (1999), there are cognitive process that fore.ter meaningful learning. For it occur, learner must be actively involved in knowledge constructs. The process must involve:

(i) selection of relevant information

(ii) organization of information in a meaningful way

(iii) Integrate information with learner prior knowledge (fig 1 refers)

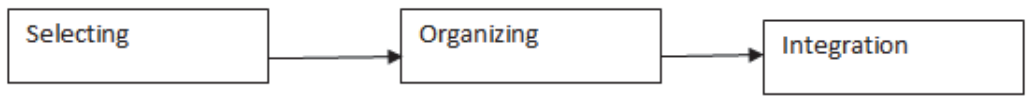

\section{Fig 1: SOI Meaningful Learning Model}

The theories above are relevant to the design of the Adaptive Interactive Cartoon Animation for teaching, reading, spelling and comprehension sub-skills in English Language. Animation and Cartoons involve and the auditory channels. Environmental sounds, musical and color effects that is technically suitable for pupils learning environment were introduced as cognitive loading.

\section{Methodology}

The study employed pretest, posttest control group research design. Two schools were purposively selected for this study because they have the required facilities like electricity and learning resources. The sample for the study is made up of 200 pupils selected from primary six in the two schools (1 public and 1 private primary school). The 200 samples were later randomly assigned to two groups, 100 pupils each in a group of two (the experimental and control groups). Two research instruments were used for data collection. The first is the "Achievement test on Reading, Spelling and Pronunciation"(ATRSP), based on the adaptive interactive animated cartoon. The test required the participants to recognize, name letters and pronounce some words in the order of increasing difficulty. The spelling aspect comprised reading words aloud as part of a sentence pupils are expected to recognize and write down correctly. The other instrument is the attitude test toward the stimulus materiel termed Adaptive Interactive Cartoon Animation"( AAICA) was designed to measure pupils' Attitude towards the adaptive interactive animated cartoons in English Language. The stimulus material used was termed the adaptive interactive cartoon animation; it is a package that was made up of animated stories within the culture of the pupils. It contained reading passage, spelling and phonological awareness. The Cartoon Animation was adapted from televised educational cartoon net work of Ogun State Television here in Nigeria. It is a computer generated images that can be used on the computer lab-tops or digital television or VCD. The study employed VCD and plasma screen. The instruments were validated using face and content validity, where three experts from Educational Technology, primary school teacher and an expert from the Psychology Department went through the instrument to check whether it measured what it was designed to measure. While the reliability for the achievement test was determined using test re -test method. A reliability coefficient of 0.68 was obtained. For the attitude test, a reliability 
of 0.75 was also obtained. Two research assistants were used; they are the class teachers and technical staff from the Department of Educational Technology. The Adaptive Interactive Cartoon Animated package was used in teaching the pupils in the experimental groups. While the control groups were taught the same content using the didactic method. A pre-test was given to the pupils before exposing them to treatment to determine pupil's attitude and entry behavior. The reading test requires pupils' proficiency in reading, recognition and pronunciation. On spelling, some words were read aloud to the pupils as part of a sentence from the content of the cartoon animated package while the pupils were expected to write down those words. On reading and pronunciation, each of the pupils reading, was recorded in an audio-taped cassette. After completion of the exercise, each of the pupil's script and recorded tapes were graded and recorded as raw-scores. An attitude questionnaire was also re-administered as post-test. All the participants were asked to give their consents to participate in the study voluntarily. The questionnaire had no identity to protect their confidentiality. The data collected were analyzed using t-test.

\section{Results}

The results obtained in respect of the data analyzed are presented below.

Table 2: Effect of the Adaptive Interactive Cartoon Animation on the Performance of Pupils

\begin{tabular}{|c|c|c|c|c|c|c|c|}
\hline Test & Group & $\mathrm{N}$ & $\overline{\mathrm{X}}$ & $\mathrm{SD}$ & $\mathrm{df}$ & $\mathrm{t}$ & $p$ \\
\hline \multirow{2}{*}{ Pre-Test } & Control & 100 & 6.90 & 1.79 & \multirow{2}{*}{198} & \multirow{2}{*}{0.28} & \multirow{2}{*}{0.05} \\
\hline & experimental & 100 & 6.97 & 1.69 & & & \\
\hline \multirow{2}{*}{ Post-Test } & Control & 100 & 7.29 & 2.17 & & & \\
\hline & Experimental & 100 & 12.57 & 279 & 198 & $14.67^{*}$ & 0.05 \\
\hline
\end{tabular}

*Significant at 0.05 level

The results of the data analyzed at the pre-test revealed that no difference exist in the entry performance of the pupils before exposure to the cartoon animation. However after exposing the pupils to treatment, there was a significant difference in the performance of pupils exposed to the interactive cartoon animation.

It therefore implied that pupils who were taught English Language using Adaptive Interactive Animated Cartoon performed significantly better that their mates who were taught using the traditional method $(t=14.67, d f=198 p<0.05)$. This implied that Adaptive Interactive Cartoon Animation was very effective in teaching English Language at the primary school level. The above findings are similar to the previous studies carried out by Edutech2010, Discover Islam UK 2010 and Adetunji(2012) On attitude of the pupils the result of the data analyzed are shown in Table 3.

Table3: Pupils Attitude towards Cartoon Animation

\begin{tabular}{|c|c|c|c|c|c|c|c|}
\hline Test & Group & $\mathrm{N}$ & $\overline{\mathrm{x}}$ & $\mathrm{SD}$ & $\mathrm{df}$ & $\mathrm{t}$ & $\mathrm{p}$ \\
\hline \multirow{2}{*}{ Pre-Test } & Control & 100 & 68.47 & 9.68 & \multirow{2}{*}{198} & \multirow{2}{*}{1.58} & \multirow{2}{*}{0.05} \\
\cline { 2 - 8 } & experimental & 100 & 68.20 & 9.47 & & & \multirow{2}{*}{198} \\
\multirow{2}{*}{ Post-Test } & Control & 100 & 62.79 & 8.60 & \multirow{2}{*}{0.05} \\
\cline { 2 - 6 } & Experimental & 100 & 73.41 & 7.23 & & \\
\hline
\end{tabular}

*Significant at 0.05

The data collected in respect of pupil's attitude towards Adaptive Interactive Cartoon Animation revealed a mean value of 68.47 for the participants in the control group and 68.20 for these in the experimental. When this was subjected to t-test, the t-calculated value of 1.58 was obtained while the critical value was 1 . It therefore implied that there was no remarkable difference in the pupil's attitude before the intervention. However after introducing the Adaptive Interactive Cartoon Animation the mean value of 62.79 was obtained for the control group and 73.41 for the experimental group. When subjected to test of significant using $t$-test, a t-calculated value of 8.47 was obtained which was very significant $(t=$ 8.47, $\mathrm{df}=198 \mathrm{P}<0.05$ ). This therefore means that the use of Adaptive Interactive Cartoon Animation significantly influenced pupil's attitudes. 


\section{Discussion of Results}

The fact that the pupils that there was a significant difference in the mean scores of the pupils that were exposed to the interactive cartoon animation and those not exposed to it at the post test is an attestation to the fact that the use of the interactive cartoon animation enhanced better performance. This was corroborated in a similar studies showed that the Mathematics skills of the students at this age was enhanced using the multimedia interactive programs. Not only this, it also enhanced the methods of teaching . The attention of the children were also enhanced when cartoon characters are used. Results also showed that there was no significant difference in learning and knowledge skills and information absorption based on gender distribution. In addition, the results comparison between little boys and girls showed no significant difference in their learning skills(Sawsan, Izzat, Mohammed and Fatima2012).In another study on the importance of cartoon animation in learning, Adiel(2003) opines that animation in education and training can perform the following items.

It enhances skill and ability: interactive animation takes less time to learn It also makes complex thing more meaningful and enjoyable to learn. Education and training are higher when information is presented via computer animation systems than traditional classroom lectures. Interactive animation increases student's imaginative-skill in education and training. Therefore, the ability to practice new concepts in a risk-free environment improves learners' skills and abilities. It is important to mention that computer animation also improve the skills and ability of instructors because they will be able to improve and change their teaching methods. Interactive: Interactivity is a mutual action between the learner, learning system, and learning material. Learners will be faster to learn, and have better attitudes toward learning when using interactive animation especially if the other techniques like audio and video are used. Interactive learning with live-action animation, simulation, video, audio, graphics, feedback, expert advice, and questions and answers keep learners interested and reinforce skills, it is also activity based and engaging. This is so because it is exciting, challenging, and fun to use, it encourages learners to return to the program again and again and again over! Through continual practice, learning is absorbed and integrated into daily performance. It is also flexible and safe, a lot of things are dangerous to be carried out in the real-life learning such as experiments in physics and chemistry. In addition, animation can offer the following issues:

- many experiments cannot be carried out in the classroom because they are dangerous, and yet learners will need these skills in the workplace;

- animation programs can represent these dangerous events without the hazards;

- if the learner were to make a mistake, the experiment can be repeated without injury.

- real-life experiences are not readily available, but an animated trip in the past brings the learner some feeling of what it must have been like;

- $\quad$ the main flexible issue of the animation is to show the non-possible matters in the real-life learning; and

- learners have more interaction with the content and are thus more likely to assimilate the knowledge, skills and concepts involved (Discovery Learning p.30).

\section{Conclusion}

The following are the conclusions made with respect to the findings of the study.

The use of Adaptive Interactive Cartoon Animation is very effective in teaching English Language in the primary schools. The performance of the selected samples used in the study improved significantly after exposure to Adaptive Interactive Cartoon Animation, the use of Adaptive Interactive Cartoon Animation also improved significantly pupil's attitude towards English Language in the primary schools in Osun State, Nigeria. The improvement in pupils performance might be hinged on fact that the package used was motivating, flexible, safe, engaging and the fact that it eliminated frustration. Based on the conclusion drawn, these recommendations are made

\section{Recommendations}

Drastic action must be taken to address the situation in our primary schools. Primary school is the foundation upon which all other educational level will be built. It is a known fact in the construction industry that the foundation of any building or structure should be solid and strong in order for it to carry the structure that will be placed upon it. In the case of our children at their tender age, the teaching strategies to be used must be motivating and creativity based. As this will allow the pupils to grow up creatively and have balanced education. A creative teaching strategies coupled with a creative 
environment can enhance progressive and creative growth in our pupils without which our children in the primary schools may not be able to face the challenges of the future. Teachers should therefore desist from destroying the lives of young children. Teachers should use the informal, progressive and cartoon animation strategies that will develop in our pupils high ordered skills needed for exploratory, experimental and creative learning.

\section{References}

Adel M. A (2003) The Advantages and Disadvantages of the Animation Technology in Education and Training. Enschede-The Netherlands, Monday.24.June.2003.

Adetunji, A.A(2012).Effects of Historical Simulations and Role Plays as Advance Organizers on Osun State Junior Secondary School Students Learning Outcomes in Basic Science. An unpublished PhD thesis submitted to the Department of Special Education and Curriculum Studies. Obafemi Awolowo University, Ile-Ife, Nigeria

Adokpaye, J. A. (2008). Phonology and its Phobia among Nigerian Secondary School Students: :A Case Study of Warn Local Government in Delta State. An unpublished B. A. Education Thesis submitted to the Faculty of Education, Obafemi Awolowo University, lle- Ife.

Ajibade, A. (2007). Effects of Interactive Instructional Compact Disc Package on the Performance of English Language Learners in School of Science in Osun State. An unpublished PhD Thesis submitted to the Department of Educational Technology, Obafemi

Awolowo University, lle-Ife.

Ayodele, S. 0. (1984). Nigeria Teacher's Perception of Learners' High Rate of Failure in English. Journal of the Nigeria English Studies Association 9 \& 2, 134-144

Barnet, M. \& Milton, M. (1995). Satellite Images and Information Technology Capability in Teaching. Teaching Geography 20, 3, $142-$ 144.

Campbell, D. I. \& Stanley, J. L. (1992). Experimental and Quasi-Experimental Design. Chicago. Rand McNally \& Co.

Cowley, K. Mayer, P \& Hamilton-Stuart, I. (2009) . Changes in Reliance on Reading and spelling Sub Skills Across Lifespan. Educational Gerontology 35, 503-522

Discover Islam UK (2010) Cartoon animation for teaching in primary schools .Retrieved from the internet @http://www.youtube.com/ watch?v=9hW3hH9_7pl

EduTech Enhancing Education (2010).Go animation - create animated cartoon for teaching retrieved from the internet on13/11/2012 @http://www.edutech.my/goanimate-create-animated-cartoon-for-teaching/

Egbowon, S. E. (1986). Effects of pictorial materials on the acquisition of English Language Composition among lower form secondary school's students. An unpublished M. A. Thesis submitted to the Department Educational Technology University of lle-lfe

Egbowon, S. F. (2005). Effects of modes of formative evaluation of video taped instruction on learner's acquisition of English Language Phonology among lower forms students. An unpublished PhD thesis submitted to the Department of Educational Technology, Obafemi Awolowo University, lle-lfe.

Egwu, S. 0. (2009). Road map for the Nigerian education sector : Federal Ministry of' Education.Abuja

Faniran, A. 0. (1998). Teaching English in the primary school: How can we make it effective and successful? The College Review 7 (1) 50-55.

Federal Republic of Nigeria (2004). National Policy on Education (NPE). Lagos. NERDC Press.

Mayer, R. F. (2001). Multimedia learning. Cambridge: Cambridge University Press.

Miller, G. A. (1956). The magical number seven plus or minus two: Some limits on our capacity for processing information. Psychology Review 63, 81-97.

Moren, R. \& Mayer, R. F (2000). A learner centered approach to multimedia: Deriving instructional design principles from cognitive theory, Wale Forest University. Electronic Journal of Computer Enhanced Learning. Utilization 5 (3)230-245

Obemeata, J. 0. (1984). The mother-tongue effect on English Language learning. Journal of the Nigeria English Studies Association 1(1 \& 2), $145-155$.

Okobi, C. P. (1992). Effects of audio-taped enrichment segment on student's performance in English Language in the Federal College of Education Kontangora, Niger State. An unpublished M. A. thesis, submitted to the Department of Educational Technology, Obafemi Awolowo University, lle-lfe.

Sawsan ,N. Izzat. A, Mohammed A, Fatima, S.(2012) Studying the Impact of Multimedia

Interactive Programs and Children Ability to Learn Basic Mathematics Skills. Acta Didactical Napocensa,5, 2, 1-16

Smith, P. L. \& Regan, T. (1999). Instructional Design. New York: John Wiley \& Sons.

Sofowora, 0. A. (2011). Enhancing the attitude and the performance of village health workers in Osun State using interactive sociodrama learning package. Journal of Agriculture and Rural Development 5, (3),15-23.

Teachers Registration Council of Nigeria (TRCN, 2010). Statistical Digest on Teachers in Nigeria. 1, 3, 6-7. 